\title{
Comparative evaluation of urodynamic profile in cases of cystocele alone or associated with uterovaginal prolapse before and after surgery
}

\author{
Paridhi Garg $^{1 *}$, Bani Sarkar ${ }^{2}$
}

\begin{abstract}
${ }^{1}$ Department of Obstetrics and Gynaecology, Rama Medical College Hospital and Research Centre, Hapur, Uttar Pradesh, India

${ }^{2}$ Department of Obstetrics and Gynaecology, Dr. Ram Manohar Lohia Hospital, New Delhi, India
\end{abstract}

Received: 14 September 2020

Accepted: 29 October 2020

\author{
*Correspondence: \\ Dr. Paridhi Garg, \\ E-mail: dr2pir@gmail.com
}

Copyright: (C) the author(s), publisher and licensee Medip Academy. This is an open-access article distributed under the terms of the Creative Commons Attribution Non-Commercial License, which permits unrestricted non-commercial use, distribution, and reproduction in any medium, provided the original work is properly cited.

\section{ABSTRACT}

Background: Pelvic organ prolapse is a bulge or protrusion of pelvic organs and their associated vaginal segments into or through the vagina. There may be structural and functional changes in the bladder and urethra post-operatively.

Methods: It was a prospective type of cohort study. The study was conducted on 30 patients with cystocele with or without uterovaginal prolapse undergoing surgery for same under Department of Obstetrics and Gynecology of Dr. Ram Manohar Lohia Hospital. Comparison of various pre-operative and post-operative urodynamic parameters were done using appropriate statistical tests.

Results: Post-operatively, statistically significant increase was observed in the bladder volumes at which patients had first and strong desire to void as well as in the maximum cystometric capacity, increase in mean compliance, increase in mean average flow rate, decrease in post-void residual volume. Though, no significant improvement was seen on peak flow rates on uroflowmetry, maximum filling detrussor pressure, mean peak flow rates, maximum voiding detrussor pressure, mean detrussor pressure at peak flow rate.

Conclusions: A pre-operative urodynamic study may be helpful in planning the site-specific repair surgery. It will also help in predicting the post-operative outcome. Urge related symptoms may not be corrected by cystocele repair alone and may require additional treatment.

Keywords: Urodynamic study, Cystocele, Uterovaginal prolapse, Pelvic organ prolapse

\section{INTRODUCTION}

Pelvic organ prolapse is a bulge or protrusion of pelvic organs and their associated vaginal segments into or through the vagina. Pelvic organ prolapse may result from weakening of the supportive structures, which may occur by actual tears or break in the supportive ligaments or by neuromuscular dysfunction or both. ${ }^{1}$ Cystocele occurs as a result of herniation of urinary bladder along the anterior wall and may be associated with voiding dysfunction such as urinary incontinence, obstruction to outflow, urgency, hesitancy and increased frequency. ${ }^{2}$ Pelvic organ prolapse leading to symptoms such as urinary incontinence, faecal incontinence, difficulty in voiding and defecation is collectively known as the "disorders of pelvic floor". 3 The normal anatomical configuration of uterus and bladder is distorted affecting the parameters like storing capacity, flow rate, peak flow rate, etc. So, urodynamic study (UDS) helps to assess the functions of the bladder in cases of pelvic organ prolapse with the help of urodynamic study. The standard urodynamic tests conducted are uroflowmetry and multichannel cystometry during filling and voiding phase. Uroflowmetry is the measurement of urine flow rate, measured in $\mathrm{ml} / \mathrm{sec}^{4}$ It is a non-invasive procedure. The modern uroflowmeter was invented by Willard M. Drake Jr., in 1946. ${ }^{5}$ Multichannel cystometry 
requires placement of catheters into the bladder and rectum and measures pressure in the rectum and bladder during bladder filling or during provocative manoeuvres. ${ }^{6}$ It also assesses the pressure changes during voiding phase, urine flow rates and the residual volume. Post-operatively, structural and functional changes may occur in the bladder and urethra such as improvements in the symptoms of incontinence, increase in flow rates, increased bladder capacity, etc.

\section{METHODS}

The study design was prospective "before and after" type of cohort study conducted from October 2011 to December 2012 conducted on 30 patients with cystocele with or without uterovaginal prolapse undergoing surgery for same under the Department of Obstetrics and Gynecology of Dr. Ram Manohar Lohia Hospital.

\section{Inclusion criteria}

The inclusion criteria for the study were as follows: all cases of cystocele alone or associated with uterovaginal prolapse, all age groups and any parity.

\section{Exclusion criteria}

The exclusion criteria for the study were as follows: urinary tract infections, urinary tract anomaly such as diverticula, bladder stones, gross hydronephrosis, urethral stenosis/stricture, associated medical disorders example: diabetes mellitus, neurological diseases, etc and previous vaginal surgery.

All patients were subjected to a preoperative uroflowmetry and cystometrography (CMG) using Laborie machine version 11. Patients were asked to void in uroflowmeter and flow rate was obtained. Pressure changes and other urodynamic parameters were recorded during filling and voiding phase. All the recruited cases underwent surgery and were subjected to post-opereative $\mathrm{CMG}$ after 3 months. During UDS, following parameters were analysed: uroflowmetry- rate of peak flow of urine; filling or storage detrussor pressure $(\operatorname{Pdet}(\mathrm{s}))$; compliance- it is the intrinsic ability of the bladder to change in volume without significant change in detrussor pressure; leakage of urine; leak point pressure: Valsalva leak point pressure(VLPP) and detrussor leak point pressure (DLPP); sensations- first urge to void; strong urge to void; maximum cystometric capacity (MCC)- volume at which one can no longer delay micturition; unstable detrussor contractions; peak detrussor pressure (maximum Pdet(v)); Pdet at max flow rate(Qmax); peak flow rate (Qmax); average flow rate (Qav); and post void residual volume (PVR).

Comparison of pre-operative and post-operative urodynamic parameters have been done using appropriate statistical tests. Statistical analysis was conducted with the Statistical package for the social science system (SPSS) version SPSS 17.0. Nominal scale variables were described using relative and absolute frequencies, and the chi square test was used to assess differences between the groups. Fisher's exact test was used if expected frequencies $<5$. $\quad \mathrm{P}<0.05$ was considered statistically significant.

\section{RESULTS}

The study was conducted on a set of 30 patients, out of which $19(63.3 \%)$ were below the age of 50 years and 11 $(36.6 \%)$ were above the age of 50 . Only $3(10 \%)$ patients had parity of two or less and $27(90 \%)$ of the patients had parity of three or more. Therefore, high parity can be a factor predisposing to pelvic organ prolapse (Table 1).

Table 1: Demographic characteristics.

\begin{tabular}{|lll|}
\hline Variable & Value & Percentage \\
\hline Age (in years) & & \\
\hline$<40$ & 7 & 23.3 \\
\hline $41-50$ & 12 & 40.0 \\
\hline $51-60$ & 4 & 13.3 \\
\hline$>60$ & 7 & 23.3 \\
\hline Parity & & \\
\hline$<3$ & 3 & 10.0 \\
\hline$=3$ & 10 & 33.3 \\
\hline$>3$ & 17 & 56.6 \\
\hline
\end{tabular}

Table 2: Urinary symptoms.

\begin{tabular}{|lll|}
\hline Symptoms & $\begin{array}{l}\text { Pre-operative } \\
\text { n(\%) }\end{array}$ & $\begin{array}{l}\text { Post-operative } \\
\text { n }(\%)\end{array}$ \\
\hline $\begin{array}{l}\text { Stress urinary } \\
\text { incontinence }\end{array}$ & $3(10)$ & $0(0)$ \\
\hline $\begin{array}{l}\text { Urge } \\
\text { incontinence }\end{array}$ & $5(16.7)$ & $3(10)$ \\
\hline Hesitancy & $13(43.3)$ & $3(10)$ \\
\hline $\begin{array}{l}\text { Feeling of } \\
\text { incomplete } \\
\text { evacuation }\end{array}$ & $8(26.7)$ & $1(3.3)$ \\
\hline
\end{tabular}

Table 3: Uroflowmetry.

\begin{tabular}{|llll|}
\hline Variable & $\begin{array}{l}\text { Pre-operative } \\
\text { mean value (in } \\
\text { ml/sec) } \mathbf{n}=\mathbf{3 0}\end{array}$ & $\begin{array}{l}\text { Post-operative } \\
\text { mean value (in } \\
\mathbf{m l} / \mathbf{s e c}) \mathbf{n = 3 0}\end{array}$ & $\begin{array}{l}\mathbf{p} \\
\text { value }\end{array}$ \\
\hline $\begin{array}{l}\text { Peak } \\
\text { flow } \\
\text { rate }\end{array}$ & 18.40 & 20.97 & 0.125 \\
\hline
\end{tabular}

The most common urinary symptom seen in patients with POP was hesitancy, seen in $13(43.4 \%)$ patients. Less frequently seen were feeling of incomplete evacuation $(26.7 \%)$, urge incontinence $(16.7 \%)$, stress incontinence (10\%). Mixed incontinence was seen in 2 patients preoperatively. Post-operatively, the component of stress incontinence was relieved, but urge incontinence persisted. 
The persistence of hesitancy in 3 patients post-operatively could be due to co-existent neuropathy (Table 2).
The difference in mean peak flow rates on uroflowmetry among the two groups was not found to be statistically significant being $18.4 \mathrm{ml} / \mathrm{s}$ pre-operatively and 20.97 postoperatively (Table 3 ).

Table 4: Bladder sensations during filling phase.

\begin{tabular}{|llll|}
\hline Sensation & $\begin{array}{l}\text { Pre-operative mean } \\
\text { value }(\mathbf{i n} \mathbf{~ m l}) \mathbf{n}=\mathbf{3 0}\end{array}$ & $\begin{array}{l}\text { Post-operative mean } \\
\text { value (in } \mathbf{m l}) \mathbf{n}=\mathbf{3 0}\end{array}$ & $\mathbf{p}$ value \\
\hline First desire to void & 238 & 329 & 0.002 \\
\hline Strong desire to void & 346.33 & 498.17 & $<0.001$ \\
\hline Maximum cystometric capacity & 405.33 & 573 & $<0.001$ \\
\hline
\end{tabular}

Table 5: Detrussor activity during filling phase.

\begin{tabular}{|c|c|c|c|}
\hline & Pre operative $(n=30)$ & Post operative $(\mathrm{n}=\mathbf{3 0})$ & \\
\hline Unstable contractions & 01 & 00 & \\
\hline Leakage of urine on CMG & 03 & 00 & \\
\hline & $\begin{array}{l}\text { Pre-operative mean } \\
\text { value }\end{array}$ & $\begin{array}{l}\text { Post-operative } \\
\text { mean value }\end{array}$ & p value \\
\hline Maximum filling detrussor pressure (in $\mathrm{cm} \mathrm{H}_{2} \mathrm{O}$ ) & 8.6 & 9.1 & 0.624 \\
\hline Compliance (in $\mathbf{~ m l} / \mathrm{cm} \mathrm{H}_{2} \mathrm{O}$ ) & 30.35 & 43.53 & 0.001 \\
\hline
\end{tabular}

Table 6: Voiding phase results.

\begin{tabular}{|c|c|c|c|}
\hline & $\begin{array}{l}\text { Pre-operative mean } \\
\text { value }\end{array}$ & $\begin{array}{l}\text { Post-operative } \\
\text { mean value }\end{array}$ & p value \\
\hline Average flow rate $\left(Q_{a v}\right)(\mathrm{ml} / \mathrm{s})$ & 10.13 & 12.23 & 0.011 \\
\hline Peak flow rate $\left(Q_{\max }\right)(\mathrm{ml} / \mathrm{s})$ & 20.93 & 19.43 & 0.351 \\
\hline Maximum voiding detrussor pressure (in $\mathrm{cm} \mathrm{H}_{2} \mathrm{O}$ ) & 41.73 & 44.66 & 0.247 \\
\hline$P_{\text {det }}$ at max flow rate $\left(Q_{\max }\right)\left(\mathrm{cm} \mathrm{H} \mathrm{H}_{2} \mathrm{O}\right)$ & 32.57 & 33.03 & 0.860 \\
\hline Post void residual volume(ml) & 93.87 & 41.17 & 0.001 \\
\hline
\end{tabular}

Post-operatively, significant increase was observed in the bladder volumes at which patients had first and strong desire to void as well as in the MCC. In the pre-operative group, 8 patients had first urge to void at a bladder volume of $<150 \mathrm{ml}$, while none in the post-operative group. Similarly, there was a significant decline in the number of patients who had strong urge to void at bladder volumes $<300 \mathrm{ml}$; being 10 pre-operatively as compared to 2 postoperatively (Table 4).

Out of the 6 patients who had symptomatic incontinence, 3 patients also had demonstrable leakage on pre-operative urodynamic study and none post-operatively. There was leakage associated with cough/valsalva in two patients. Leakage of $22 \mathrm{ml}$ at bladder volume of $90 \mathrm{ml}$ and VLPP $84 \mathrm{~cm} \mathrm{H}_{2} \mathrm{O}$ in one patient and leakage of $18 \mathrm{ml}$ at bladder volume of $540 \mathrm{ml}$ and VLPP $120 \mathrm{~cm} \mathrm{H}_{2} \mathrm{O}$. One another patient leaked $22 \mathrm{ml}$ associated with overactive bladder (OAB) contraction at volume of $112 \mathrm{ml}$ and DLPP $18 \mathrm{~cm}$ $\mathrm{H}_{2} \mathrm{O}$. Unstable detrussor contraction prior to surgery was seen in 1 patient and none post-operatively. Maximum filling/storage detrussor pressure $<6 \mathrm{~cm} \mathrm{H}_{2} \mathrm{O}$ was seen in 12 patients pre-operatively and 11 patients post- operatively. There was no statistically significant change in the maximum filling detrussor pressure; $\max \mathrm{P}_{\operatorname{det}}(\mathrm{s})$ being $8.6 \mathrm{~cm} \mathrm{H}_{2} \mathrm{O}$ in the pre-operative group and $9.1 \mathrm{~cm}$ $\mathrm{H}_{2} \mathrm{O}$ in the post-operative group. Compliance $>20 \mathrm{ml} / \mathrm{cm}$ $\mathrm{H}_{2} \mathrm{O}$ was seen in 22 patients pre-operatively as compared to 27 patients post-operatively. A statistically significant increase in the mean compliance was seen post-operatively (Table 5).

During voiding studies, a statistically significant increase in mean average flow rate was seen from $10.13 \mathrm{ml} / \mathrm{s}$ in the pre-operative group to $12.23 \mathrm{ml} / \mathrm{s}$ in the post-operatively. Though, no statistically significant change was seen in mean peak flow rates; being $20.93 \mathrm{ml} / \mathrm{s}$ pre-operatively and 19.43 post-operatively. There was no statistically significant change in the maximum voiding detrussor pressure; maximum $\mathrm{P}_{\operatorname{det}(\mathrm{v})}$ being $41.73 \mathrm{~cm} \mathrm{H}_{2} \mathrm{O}$ in the preoperative group and $44.66 \mathrm{~cm} \mathrm{H}_{2} \mathrm{O}$ in the post-operative group. Detrussor pressure at peak flow rate was in the range of $20-40 \mathrm{~cm} \mathrm{H}_{2} \mathrm{O}$ in 18 patients pre-operatively as compared to 23 patients post-operatively. The mean values for detrussor pressure at peak flow rate were more than 25 $\mathrm{cm} \mathrm{H}_{2} \mathrm{O}$. However, there was no significant change in the 
mean detrussor pressure at peak flow rate in the two groups.

There was a statistically significant decrease in post-void residual volume from $93.87 \mathrm{ml}$ in pre-operative group as compared to $41.17 \mathrm{ml}$ in the post-operative group (Table $6)$.

\section{DISCUSSION}

Pelvic organ prolapse is a health concern affecting millions of women worldwide. It is more common in females of high parity, which was also observed by Panicker et al and Wolter et al. ${ }^{7,8}$ The significant improvement observed in stress incontinence post-operatively can be because of cystocele repair and Kelly's stitch applied during surgery. The persistence of urge incontinence and hesitancy postoperatively could be due to anatomic distortion of lower urinary tract. The somatic and autonomic innervations of the pelvis could be disturbed by reconstructive pelvic surgery, which could lead to persistence of the voiding symptoms. ${ }^{7}$ The results were similar to Wall et al and Chaikin et al. ${ }^{8,10}$

On uroflowmetry, insignificant increase in the peak flow rate could be because patients had a pre-operative $\mathrm{Q}_{\max }$ within normal range.

On CMG during filling phase, there was a significant increase in the bladder volumes at which patients had first urge and strong urge to micturate as well as the maximum cystometric capacity post-operatively. The findings are similar to the study of Panicker et al. ${ }^{7}$ This could be related to improved bladder compliance allowing more bladder filling.

Apparent poorer sensory functions in post-operative group as suggested by significant increase in first urge, strong urge and MCC in the post-operative group may be related to improved bladder compliance allowing more bladder filling before reaching a bladder pressure enough to stimulate stretch or pressure receptors in the bladder.

Maximum filling detrussor pressure was found to be within normal range pre-operatively with no significant change post-surgery, this could be because of no gross impairment of functioning of detrussor muscle due to presence of cystocoele. The reduced compliance in preoperative group could be because prolapsed bladder is not able to stretch easily, with significant improvement postoperatively.

During voiding CMG, an improved average flow rate while no change in peak flow rates could be due to improvement in overall micturition time consequent to surgical correction of cystocoele. So, the patient has to strain less to evacuate urine collected in the prolapsed portion of the bladder.
No significant change in peak detrussor pressure and detrussor pressure at peak flow rates is in accordance with the study of Panicker et al. ${ }^{7}$ This could be because advanced prolapse gives rise to mild degrees of urethral obstruction. The significant decrease in post-void residual urine volume suggests an improved bladder evacuation post-operatively. The results were similar to Panicker et al. $^{7}$

\section{CONCLUSION}

To conclude, the present study shows improvement in urodynamic parameters after surgery. Hence, patients can be counselled regarding the improvement or worsening of symptom pre-operatively and appearance of any de-novo symptom after surgery. If stress incontinence is present before surgery on urodynamic study, an additional urethropexy procedure can be undertaken. The study also shows that urge related symptoms may not be corrected by cystocele repair alone and may require additional treatment such as anti-cholinergic drugs. Thus, a preoperative urodynamic study may be helpful in planning the site-specific repair surgery. It will also help in predicting the post-operative outcome. Hence, for better postoperative outcome, patients with uterovaginal prolapse should undergo urodynamic study.

\section{ACKNOWLEDGMENTS}

Authors are extremely thankful to all the participants for their valuable contribution to carry out this study. This study and the research would not have been possible without the exceptional support of my supervisor. All the tests required for this research have been done free of cost by hospital and no charge was taken from the patients.

\section{Funding: No funding sources}

Conflict of interest: None declared

Ethical approval: The study was approved by the Institutional Ethics Committee

\section{REFERENCES}

1. Ballard AV, Meyer I, Varner RE, Gleason JL, Richter HE. Pelvic Organ Prolapse. In: Berek \& Novak's Gynecology. 15th edition. Lippincott Williams \&Wilkins. 2012;906-39.

2. Pelvic organ prolapse. ACOG. Technical Bulletin. Int J Gynecol Obstet. 1996;52:197-205.

3. Jackson SL, Weber AM, Hull TL, Mitchinson AR, Walters MD. Incontinence in women with Pelvic Organ Prolapse. Int J Gynecol Obstet. 1997;89:423-7.

4. Miklos JR. Uroflowmetry. In: Clinical Urogynecology. 2nd edition. Churchill Livingstone. 2000;118-24.

5. Michael B Chancellor, Rivas DA, Mulholland SG, Drake Jr WM. The Invention of the Modern Uroflowmeter by Willard M Drake, Jr at Jefferson Medical College. Urol. 1998;51(4):671-4. 
6. Miklos JR. Cystometry and videocystourethrography. In: Clinical Urogynecology. 2nd edition. Churchill Livingstone. 2000;95-96.

7. Panicker R, Sriniwas S. Urodynamic changes in pelvic organ prolapse and the role surgery. Medic $\mathrm{J}$ Arm Forc Ind. 2009;65:221-4.

8. Wolter CE, Kaufman MR, Duffy JW, Scarpero HM, Dmochowski RR. Mixed incontinence and cystocoele: postoperative urge symptoms are not predicted by preoperative urodynamics. Int Urogynecol J. 2011;22(3):321-5.

9. Wall LL, Hewitt JK. Urodynamic characteristics of women with complete post hysterectomy vaginal vault prolape. Urology. 1994;44(3):336-41.
10. Chaikin DC, Groutz A, Blaivas JG. Predicting the need for anticholinergics for anti-incontinence surgery in continent women undergoing repair of severe urogenital prolapsed. J Urol. 2000;163(2):5314.

Cite this article as: Garg P, Sarkar B. Comparative evaluation of urodynamic profile in cases of cystocele alone or associated with uterovaginal prolapse before and after surgery. Int J Reprod Contracept Obstet Gynecol 2020;9:4980-4. 